\title{
Evaluasi Sensitivitas Antibiotik dengan Demam Neutropenia
}

\author{
Sulaiman Hamid, Pudjo Hagung Widjajanto, Ida Safitri Laksono \\ Bagian Ilmu Kesehatan Anak Fakultas Kedokteran Universitas Gadjah Mada/RSUP Dr. Sardjito, \\ Yogyakarta
}

Latar belakang. Pemberian antibiotik sangat penting untuk menurunkan angka kematian pasien demam neutropenia. Di sisi lain, penggunaan antibiotik jangka panjang akan mengubah pola patogen dan uji sensitivitas terhadap antibiotik.

Tujuan. Mencari pola patogen, menilai sensitivitas cefotaxime dan gentamicin sebagai antibiotik lini pertama, dan mendapatkan antibiotik alternatif pada demam neutropenia.

Metode. Penelitian potong lintang dilakukan pada anak demam neutropenia yang dirawat di Bangsal Onkologi Anak RSUP Dr. Sardjito periode Januari 2004 sampai Desember 2009. Kriteria inklusi adalah demam (didefinisikan sebagai suhu tubuh $\geq 38,3^{\circ} \mathrm{C}$ atau $\geq 38,0^{\circ} \mathrm{C}$ pada dua kali pengukuran selang 1 jam), neutropenia (absolute neutrophil count/ANC $<500 \mathrm{sel} / \mathrm{mm}^{3}$ atau $<1000 \mathrm{sel} / \mathrm{mm}^{3}$ yang diperkirakan akan turun menjadi $<500 \mathrm{sel} / \mathrm{mm}^{3}$ dalam $48 \mathrm{jam}$ ), dan hasil biakan positif. Uji sensitivitas dinilai dengan menggunakan disc diffusion method.

Hasil. Terdapat 205 episode neutropenia dari 188 subjek, 135 episode di antaranya mengalami demam

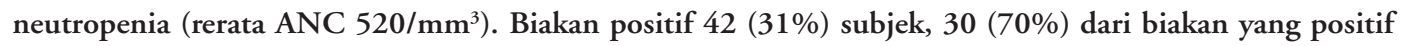
merupakan bakteri Gram negatif. Pseudomonas aeruginosa (19\%) dan Escherichia coli (19\%) merupakan patogen terbanyak dijumpai pada biakan. Hasil uji sensitivitas antibiotik invitro, gentamicin sensitif pada $45 \%$ biakan sedangkan cefotaxime $29 \%$.

Kesimpulan. Bakteri Gram negatif merupakan penyebab utama demam neutropenia. Sensitivitas cefotaxime lebih rendah apabila dibandingkan dengan antibiotik yang lain. Cefpirome, cefepime dan ampicillin-sulbactam direkomendasikan untuk menggantikan cefotaxime sebagai obat yang dikombinasikan dengan gentamicin pada pengobatan demam neutropenia. Sari Pediatri 2013;15(4):220-4.

Kata kunci: demam neutropenia, sensitivitas antibiotik

\footnotetext{
Alamat korespondensi:

Dr. Sulaiman Hamid, Sp.A. Bagian Ilmu Kesehatan Anak, Fakultas Kedokteran Universitas Gadjah Mada/RSUP. Dr.Sardjito, Jalan Kesehatan No. 1 Sekip Yogyakarta 55284, Indonesia. Telp. (0274) 561616, Fax. (0274) 583745. Email:nur_laili@idai.or.id
}

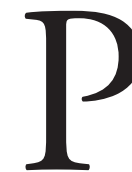
emberian antibiotik merupakan prosedur baku bagi pasien keganasan hematologi dengan demam neutropenia. Neutropenia atau jumlah neutrofil $<1500 / \mathrm{mm}^{3}$ merupakan kondisi yang mencerminkan immunitas selular tubuh yang lemah sehingga sangat rentan terhadap infeksi. ${ }^{1,2}$ 
Pemberian antibiotik sedini mungkin pada demam neutropenia akan menurunkan angka kematian secara nyata. ${ }^{3,4}$

Terdapat banyak pilihan antibiotik yang dapat digunakan untuk pengobatan demam neutropenia. Antibiotik yang diberikan sesuai dengan kelompok risiko. Risiko rendah apabila anak tampak stabil, tidak ada komorbid, dan neutropenia diperkirakan akan membaik dalam 7 hari. $^{2}$ Risiko tinggi apabila terdapat peningkatan risiko untuk terjadi infeksi berat, seperti prolonged neutropenia, sedang mendapat kemoterapi intensif, keterlibatan sumsum tulang, atau anak tampak sakit berat (distres respirasi, hipoksemia, hipertermia, takikardia, takipnea, nyeri perut mendadak dan terjadi defisit neurologis). ${ }^{2}$ Anak dengan risiko rendah diberikan mono- atau multi-drugs therapy secara oral, sedangkan risiko tinggi diberikan multidrugs therapy secara intra vena. ${ }^{5}$ Pengobatan tersebut merupakan pengobatan empirik didasarkan pada pola bakteri dan sensitivitas terhadap antibiotik di rumah sakit setempat. ${ }^{1-3,6,7}$

Kombinasi cefotaksim dan gentamisin merupakan obat pilihan pertama untuk demam neutropenia di Sub Bagian Hematologi dan Onkologi, Instalasi Kesehatan Anak RSUP Dr. Sardjito, Yogyakarta. Kedua antibiotik tersebut lebih sensitif untuk bakteri Gram negatif sesuai dengan mayoritas bakteri yang dijumpai pada demam neutropenia. ${ }^{2}$ Penggunaan antibiotik dalam waktu lama akan memberikan risiko terjadi resistensi. Hasil beberapa penelitian menunjukkan terjadi peningkatan resistensi terhadap cefotaksim. ${ }^{7,8} \mathrm{Di}$ sisi lain, telah terjadi perubahan pola bakteri sebagai akibat dari peningkatan tindakan medis dan penggunaan antibiotik spektrum luas. ${ }^{2}$ Perubahan pola bakteri tersebut akan memengaruhi pemilihan antibiotik. ${ }^{7}$
Berdasarkan uraian pada latar belakang, penelitian ini ditujukan untuk mengidentifikasi pola bakteri terkini pada demam neutropenia, mengevaluasi sensitivitas bakteri terhadap cefotaksim dan gentamisin serta mencari antibiotik alternatif. Hasil penelitian akan dijadikan acuan dalam memberikan antibiotik yang tepat berdasarkan pola dan sensitivitas bakteri.

\section{Metode}

Telah dilakukan studi potong lintang pada pasien keganasan dengan demam neutropenia yang dirawat di bangsal Onkologi Anak RSUP Dr. Sardjito dari bulan Januari 2005 sampai dengan Desember 2009, dan hasil biakan positif. Diagnosis demam ditegakkan berdasarkan suhu $>38,3^{\circ} \mathrm{C}$ pada sekali pengukuran atau $\geq 38^{\circ} \mathrm{C}$ pada dua kali pengukuran dengan rentang waktu satu jam. Neutropenia ditegakkan apabila absolut neutrophil count (ANC) $<500 / \mathrm{mm}^{3}$ atau ANC $<1000 / \mathrm{mm}^{3}$ dengan kecenderungan turun menjadi $<500 / \mathrm{mm}^{3}$ dalam 48 jam. ${ }^{2,4,6,9}$ Data penelitian diambil dari catatan medik subyek, meliputi identitas, hasil biakan dan data lain yang diperlukan. Sensitivitas dinyatakan sebagai persentase bakteri yang sensitif terhadap antibiotik.

\section{Hasil}

Didapatkan 205 episode neutropenia, 135 (66\%) di antaranya mengalami demam neutropenia. Di antara 135 kasus demam neutropenia, biakan bakteri tumbuh 42 (31\%) kasus dari spesimen darah, feses, urin, dan sputum. Rerata jumlah ANC $435 / \mathrm{mm}^{3}$ dan rerata

Tabel 1. Karakteristik subyek penelitian

\begin{tabular}{|c|c|c|c|}
\hline Variabel & n (\%) & Median & Rentang \\
\hline \multicolumn{4}{|l|}{ Jenis kelamin } \\
\hline $\begin{array}{l}\text { Laki-laki } \\
\text { Perempuan }\end{array}$ & $12(45)$ & & \\
\hline Perempuan & $30(65)$ & & \\
\hline Umur (tahun) & & 4,5 & $1-16$ \\
\hline Lama demam saat diambil biakan (hari) & & 3 & $1-8$ \\
\hline Absolut neutrophil count $\left(/ \mathrm{mm}^{3}\right)$ & & 383 & $0-917$ \\
\hline Jumlah leukosit $\left(/ \mathrm{mm}^{3}\right)$ & & 2504 & $200-21.000$ \\
\hline Asal spesimen biakan positif & & & \\
\hline Darah & $19(45)$ & & \\
\hline Feses & $12(29)$ & & \\
\hline Urin & $9(21)$ & & \\
\hline Sputum & $2(5)$ & & \\
\hline
\end{tabular}


jumlah leukosit $2504 / \mathrm{mm}^{3}$. Karakteristik subyek penelitian tertera pada Tabel 1. Di antara 42 biakan yang tumbuh, bakteri Gram negatif dijumpai pada 30 (71\%) biakan dan Gram positif pada 12 (29\%) biakan. Bakteri terbanyak adalah Escherichia coli 8 (19\%) dan Pseudomonas aeruginosa 8 (19\%) biakan. Jenis bakteri yang tumbuh dalam biakan tertera pada Tabel 2 .

Uji sensitivitas terhadap amikasin dan fosfomisin mempunyai persentase terbesar, yaitu sensitif $74 \%$ bakteri yang tumbuh pada biakan, sedangkan amoksisilin dan Ampisilin mempunyai persentase

Tabel 2. Jenis bakteri yang tumbuh dalam biakan

\begin{tabular}{lll}
\hline Jenis bakteri & $\mathrm{n}$ & $\%$ \\
\hline Escherichia coli & 8 & 19 \\
Pseudomonas aeruginosa & 8 & 19 \\
Staphylococcus coagulase negative & 5 & 12 \\
Klebsiella pneumonia & 3 & 7 \\
Klebsiella oxytoca & 3 & 7 \\
Staphylococcus epidermidis & 3 & 7 \\
Acinetobacter calcoaceticus & 2 & 5 \\
Staphylococcus sapropiticus & 2 & 5 \\
Enterobakter aerogenes & 2 & 5 \\
Citrobakter freundii & 2 & 5 \\
Salmonella typhi & 1 & 5 \\
\hline
\end{tabular}

Tabel 3. Persentase sensitivitas dan resistensi antibiotik

\begin{tabular}{lcc}
\hline Antibiotik & $\begin{array}{c}\text { Sensitif } \\
\mathrm{n}(\%)\end{array}$ & $\begin{array}{c}\text { Resisten } \\
\mathrm{n}(\%)\end{array}$ \\
\hline Amikasin & $28(74)$ & $10(26)$ \\
Fosfomisin & $25(74)$ & $9(26)$ \\
Netilmisin & $18(64)$ & $10(36)$ \\
Sefpirom & $18(58)$ & $13(42)$ \\
Sefepim & $21(54)$ & $18(46)$ \\
Siprofloksasin & $18(47)$ & $20(53)$ \\
Gentamisin & $14(45)$ & $17(55)$ \\
Ampisillin-sulbaktam & $14(45)$ & $17(55)$ \\
Tobramisin & $12(44)$ & $15(56)$ \\
Tetrasiklin & $16(41)$ & $23(59)$ \\
Trimetroprim & $9(36)$ & $16(64)$ \\
Seftazidim & $13(35)$ & $24(65)$ \\
Sulfametoksazol & $10(29)$ & $24(71)$ \\
Cefotaksime & $12(29)$ & $29(71)$ \\
Ceftriakson & $10(25)$ & $30(75)$ \\
Kloramfenikol & $7(25)$ & $21(75)$ \\
Amoksisilin & $3(19)$ & $81(81)$ \\
Ampisilin & $4(13)$ & $27(87)$ \\
\hline
\end{tabular}

sensitivitas terendah, yaitu 19\% dan 13\%. Gentamisin sensitif pada $45 \%$ biakan yang tumbuh, sedangkan cefotaksim 29\%.

Antibiotik yang mempunyai sensitivitas tinggi terhadap Gram negatif merupakan pilihan untuk demam neutropenia. Profil sensitivitas beberapa antibiotik golongan aminoglikosida, ceflosporin dan ampisillin-sulbaktam terhadap bakteri Gram positif dan Gram negatif tertera pada Tabel 4.

Tabel 4. Persentase sensitivitas antibiotik terhadap bakteri Gram negatif dan positif

\begin{tabular}{lcc}
\hline \multirow{2}{*}{ Antibiotik } & \multicolumn{2}{c}{ Isolasi } \\
\cline { 2 - 3 } & $\begin{array}{c}\text { Gram negatif } \\
\mathrm{n}(\%)\end{array}$ & $\begin{array}{c}\text { Gram positif } \\
\mathrm{n}(\%)\end{array}$ \\
\hline Aminoglikosida & & \\
$\quad$ Gentamisin & $10(38)$ & $4(80)$ \\
Amikasin & $19(70)$ & $9(82)$ \\
Netilmisin & $14(58)$ & $4(100)$ \\
Cefalosporin & & \\
Cefotaksim & $6(21)$ & $6(46)$ \\
Sefpirom & $11(48)$ & $8(100)$ \\
Sefepim & $12(41)$ & $9(90)$ \\
Ampisillin-Sulbaktam & $5(24)$ & $9(90)$ \\
\hline
\end{tabular}

\section{Pembahasan}

Penurunan angka neutrofil yang menyertai kemoterapi berisiko mengalami infeksi berat. Oleh karena itu, pasien demam neutropenia dengan risiko tinggi harus dirawat, dan memerlukan pemberian antibiotik spektrum luas intravena. Pada anak yang mendapat kemoterapi, jejas pada mukosa akibat kemoterapi akan mengakibatkan kerusakan integritas mukosa sehingga akan timbul mukositis pada saluran cerna. Mukosistis merupakan pintu masuk (port de entre) bagi bakteri saluran cerna sehingga dapat mencapai aliran darah..$^{1-3,10}$

Bakteri Gram negatif merupakan bakteri terbanyak penyebab demam neutropenia. ${ }^{2,11}$ Bakteri tersebut diduga berasal dari saluran cerna yang mengalami translokasi akibat penurunan daya tahan tubuh pasien. Hasil penelitian kami juga menunjukkan bahwa bakteri Gram negatif masih menjadi penyebab terbanyak demam neutropenia (69\%), dengan penyebab terbanyak Pseudomonas aeruginosa (19\%) dan Escherichia coli (19\%). Hasil tersebut sesuai dengan penelitan yang dilakukan Hakim $\mathrm{dkk}^{12}$ yang menemukan bahwa 
Pseudomonas aeruginosa dan Escherichia coli merupakan bakteri terbanyak ditemukan pada demam neutropenia. Escherichia coli merupakan bakteri yang berada di dalam saluran cerna, sedangkan Pseudomonas aeruginosa merupakan bakteri yang sering dijumpai pada infeksi nosokomial. Beberapa penelitian terakhir, mengungkapkan bahwa telah terjadi perubahan pola bakteri sebagai akibat penggunaan alat medis invasif yang meningkat dan penggunaan antibiotik spektrum luas. ${ }^{2,11}$

Penilaian terhadap risiko terjadi infeksi berat sangat dibutuhkan dalam penentuan jenis, cara, dan lama pemberian antibiotik. Pasien dengan risiko rendah adalah pasien yang secara klinis tampak stabil, tidak terdapat komorbid, jumlah neutrofil diprediksi akan naik, atau menderita tumor solid bukan leukemia atau limfoma. Pada pasien dengan risiko rendah, pemberian antibiotik oral sudah memadai untuk mengendalikan infeksi, sedangkan pasien dengan risiko tinggi, pemberian antibiotik intravena kombinasi sudah merupakan prosedur baku. ${ }^{2,9,10}$

Sefotaksim dan gentamisin merupakan antibiotik kombinasi pilihan pertama yang digunakan untuk demam neutropenia di Bangsal Onkologi Anak RSUP Dr.Sardjito. Pilihan kombinasi tersebut sesuai dengan pola bakteri yang sebagian besar karena Gram negatif. Gentamisin merupakan antibiotik golongan aminoglikosida yang mempunyai khasiat bakterisidal, bekerja dengan menghambat sintesis protein bakteri. ${ }^{11,13,14}$ Pada penelitian kami, bakteri yang sensitif terhadap gentamisin $45 \%$. Sensitivitas gentamisin terhadap bakteri Gram negatif 38\%, sedangkan terhadap Gram positif $80 \%$. Persentase sensitivitas gentamisin terhadap bakteri Gram negatif kurang dari 50\%. Risiko kegagalan pengobatan cukup tinggi jika gentamisin diberikan sebagai obat tunggal. Walaupun demikian, gentamisin masih cukup sensitif, terbukti secara umum menempati urutan ke 7 dari 18 antibiotik yang diuji. Kombinasi dengan antibiotik yang tepat dan sinergis akan dapat menutup kekurangan ini. ${ }^{4,7,15}$

Hasil penelitian kami sesuai dengan penelitian Ansari $\mathrm{dkk}^{16}$ yang menemukan amikasin masih mempunyai sensitivitas yang tinggi terhadap bakteri. Amikasin sensitif pada $74 \%$ bakteri yang tumbuh pada biakan. Amikasin juga sensitif terhadap bakteri Gram negatif (70\%) maupun Gram positif (83\%). Aminoglikosida yang lain, netilmisin, sensitif pada $64 \%$ biakan yang tumbuh. Sensitivitas netimisin pada Gram negatif 58\% dan Gram positif 100\%. Melihat profil sensitivitas dari ketiga obat golongan aminoglikosida tersebut, tampak bahwa di tempat kami gentamisin mempunyai sensitivitas yang lebih rendah dibandingkan amikasin dan netilmisin, baik secara umum maupun menurut jenis bakterinya.

Sefotaksim merupakan antibiotik golongan sefalosporin generasi ke tiga. Obat tersebut mempunyai khasiat bakterisidal dan bekerja dengan menghambat sintesis mukopeptida pada dinding sel bakteri. ${ }^{13,17}$ Pada penelitian kami, sefotaksim mempunyai sensitivitas yang rendah (29\%). Sefotaksim sensitif $21 \%$ pada Gram negatif dari bakteri yang tumbuh, sedangkan Gram positif 46\%. Hasil tersebut sesuai dengan beberapa penelitian yang melaporkan bahwa resistensi bakteri terhadap sefotaksim meningkat pesat. Peningkatan resistensi kemungkinan besar diakibatkan oleh pemakaian sefotaksim yang tidak berdasarkan indikasi yang tepat. ${ }^{8,18}$ Sefpirom, sefepim, dan ampisillin-sulbaktam mempunyai sensitivitas lebih baik dibandingkan dengan sefotaksim, baik untuk kelompok Gram negatif maupun Gram positif. Sefpirom sensitif $58 \%$ bakteri yang tumbuh pada biakan, sefepim sensitif 54\%, dan ampisillin-sulbaktamsensitif 45\%. Berdasarkan hasil tersebut sefpirom, sefepim, atau ampisillin-sulbaktam sebaiknya dipertimbangkan untuk menggantikan sefotaksim sebagai salah satu obat yang dikombinasikan dengan aminoglikosida pada pengobatan demam neutropenia. ${ }^{2,18}$

Kekurangan penelitian ini adalah sensitivitas yang diperoleh hanya berupa sensitivitas invitro. Keberhasilan pengobatan dipengaruhi banyak faktor, di antaranya oleh farmakokinetik dan farmakodinamik obat serta kondisi fisik pasien. Oleh karena itu, perlu dilakukan penelitian lanjutan untuk menilai efektifitas kombinasi sefotaksim dan gentamisin secara invivo.

\section{Kesimpulan}

Bakteri Gram negatif masih merupakan penyebab tersering demam neutropenia di Bangsal Onkologi Anak RSUP Dr. Sardjito, sedangkan bakteri terbanyak adalah Escherichia coli dan Pseudomonas aeruginosa. Pseudomonas aeruginosa sebagai bakteri terbanyak perlu dilakukan penelitian lebih lanjut untuk melihat apakah bakteri tersebut berawal dar akibat dari infeksi nosokomial. Sefpirom, sefepim, atau ampisillin-sulbaktam dapat dipertimbangkan untuk 
menggantikan sefotaksim sebagai obat lini pertama pada demam neutropenia. Obat-obat tersebut mempunyai sensitivitas lebih tinggi dibandingkan dengan sefotaksim, baik secara umum maupun terhadap bakteri Gram negatif dan Gram positif.

\section{Daftar pustaka}

1. Santolaya ME, Villarroel M, Avendan LF, Cofre J. Discontinuation of antimicrobial therapy for febrile, neutropenic children with cancer: a prospective study. Clin Infect Dis 1997;25:92-7.

2. Palazzi DL. The use of antimicrobial agents in children with fever during chemotherapy-induced neutropenia. The importance of risk stratification. Pediatr Infect Dis J 2011;30:887-90.

3. Meckler G, Lindemulder S. Fever and neutropenia in pediatric patients with cancer. Emerg Med Clin N Am 2009;27:525-44.

4. Mendes AVM, Sapolnik R, Mendonça N. New guidelines for the clinical management of febrile neutropenia and sepsis in pediatric oncology patients. J Pediat 2007;83:2(Suppl)

5. Oppenheim BA, Anderson H. Management of febrile neutropenia in low risk cancer patients. Thorax 2000;55(Suppl 1):S63-9.

6. Sung L, Johnston DL. Approach to febrile neutropenia in the general paediatric setting. Paediatr Child Health 2007;12:1.

7. Hughes WT, Feld R, Armstrong D. Guidelines for the use of antimicrobial agents in neutropenic patients with cancer. Clin Infect Dis 2002;34:730-51.

8. Glatz K, Szabo D, Bariszova D, Rosgonyi F. Emergence of extremely high penicillin and cefotaxime resistance and high-level levofloxacin resistance in clinical isolates of streptococcus pneumoniae in Hungary. J Microbial Chem 2001;48:731-4.

9. Naurois J, Basso IN, Gill MJ, Marti FM, Cullen MH, Roila F. Management of febrile neutropenia: ESMO clinical practice guidelines. Annuals Oncol 2010;21
(Suppl 5):252-6.

10. Gaur AH, Flynn PM, Shenep JL. Optimum management of pediatric patients with fever and neutropenia. Indian J Pediatr 2004;71:825-35.

11. Bacalla RC. Changing in-vitro sensitivity of pseudomonas aeruginosa to aminoglycosides at cebu velez general hospital. Phil J Microbiol Infect Dis 1988;17:19-21.

12. Hakim H, Flynn PM, Knapp KM, Kumar D, Srivastava, Etiology and clinical course of febrile neutropenia in childrenwith cancer. J Pediatr Hematol Oncol 2009;31:623-9.

13. Ogle JW. Current diagnosis and treatment in pediatrics. Antimicrobial therapy. Edisi ke-18. New York: The McGraw-Hill Companies;2007.

14. Chambers H. Antimicrobial agents: the aminoglycosides. Dalam: Limbird LE, Hardman JG, Goodman \& Gilman's, penyunting. The pharmacological basis of theurapeutics. Edisi ke-10. New York: The McGraw-Hill Companies;2001.

15. Bejon P, Mwangi I, Ngetsa C. Invasive gram-negative bacilli are frequently resistant to standard antibiotics for children admitted to hospital in Kilifi, Kenya. J Antimicrob Chem 2005;56,232-5.

16. Ansari SH, Nasim S, Ahmed A. Febrile neutropenia in paediatric peripheral blood stem cell transplantation invitro sensitivity data and clinical response to empirical antibiotic therapy. JCPSP 2006;16:704-8.

17. Petry Jr WA. Antimicrobial agents: penicillins, chephalosporins and other $\beta$-lactam antibiotics. Dalam: Limbird LE, Hardman JG, Goodman \& Gilman's. The pharmacological basis of theurapeutics. Edisi ke10. New York: The McGraw-Hill Companies; 2001.

18. Tomc JF, Dougherty TJ, Deorio FJ, Jacobson VS, Kessler RE, Activity of cefepime against ceftazidimeand cefotaxime-resistant gram-negative bacteria and its relationship to 1-lactamase levels. Antimicrob Agents Chem 1989;498-502.

19. Basu SK, Fernandez ID, Fisher SG, Asselin BL, Lyman GH. Length of stay and mortality associated with febrile neutropenia among children with cancer. J Clin Oncol 2005;23:7958-66. 